Reprod. Nutr. Dévelop., 1984, 24 (4), 379-386.

\title{
Effects of Maillard's reaction products on apparent mineral absorption in different parts of the digestive tract. The role of microflora
}

\author{
Claude ANDRIEUX, E. SACQUET
}

Laboratoire des Animaux sans Germes, CNRS, I.N.R.A., 78350 Jouy-en-Josas, France.

Summary. 1.5 and $3 \%$ of Maillard's reaction products (MRP), prepared by heating glycine and glucose, were incorporated into a semi-synthetic diet. The diet was sterilized by irradiation. MRP caused a change in apparent absorption of calcium and magnesium in germfree (GF) and conventional (CV) rats. The absorption of these minerals was reduced in the small intestine of $\mathrm{CV}$ and GF, perhaps due to the action of MRP on enterocyte metabolism. This effect was compensated for only in $\mathrm{CV}$ rats by increased absorption of these minerals in the cecum and the colon. The presence of microflora and the increase in cecal volume in CV rats suggested that MRP fermentation increased mineral absorption in the cecum and colon. However, although total apparent absorption of magnesium and phosphorus was higher in CV rats ingesting MRP, the urinary excretion of these minerals was also higher and their retention was not better. The effect of MRP in GF rats was not compensated for in the cecum, and mineral retention was significantly reduced in GF rats ingesting MRP.

\section{Introduction.}

In a previous study we reported that the retention of several minerals ( $\mathrm{Ca}$, $\mathrm{Mg}, \mathrm{P}, \mathrm{Ca}$ ) was reduced in germfree (GF) rats receiving a diet containing Maillard's reaction products (MRP) prepared from glucose and glycine. These substances seemed to have no effect in conventional (CV) rats (Andrieux, Sacquet and Guéguen, 1980). These results evidenced probable destruction of MRP by the microflora, as already reported by Nesheim and Carpenter (1967), Valle-Riestra and Barnes (1970), Sgarbieri et al. (1972), Adrian and Frangne (1973), Tanaka, Lee and Chichester (1975), Johnson, Baker and Perkins (1979).

Many questions rest in suspense. In our previous work we could not determine the mineral absorption in GF rats because MRP produced diarrhea in those rats and thus prevented good separation of urine and feces. In the present work we have studied (1) the effect of MRP on total apparent calcium, magnesium and phosphorus absorption in CV and GF rats ; $(2)$ the site of MRP action in the digestive tract ; (3) the effects of the microflora ; the microflora, 
although it destroys the MRP, must be abundant to do so and thus the MRP are destroyed in the cecum and colon.

We have used a technique permitting the estimate in vivo of apparent mineral absorption in different parts of the digestive tract, i.e. the small intestine, cecum and colon.

\section{Material and methods.}

The MRP were prepared by heating a pasty medium of an equimolecular mixture of glucose and glycine at $120^{\circ} \mathrm{C}$ for $20 \mathrm{~min}$. In our conditions, $16 \%$ glucose and $25 \%$ glycine were not converted. After dilution, the MRP were lyophilized and incorporated into the diet (Andrieux, Sacquet and Guéguen, 1980).

Three-month old Fischer strain 344 male rats (GF kept in Trexler isolators and $\mathrm{CV}$ raised in a conventional rat room) were given a semi-synthetic diet (table 1) for 4 weeks containing $0 \%$ (diet C), $1.5 \%$ (diet M1.5) or $3 \%$ (diet $\mathrm{M} 3)$ of MRP. At the 5 th week, $0.2 \%$ of titanium dioxide $\left(\mathrm{TiO}_{2}\right)$ was added to the diet as a transit marker. The various diets were sterilized by $\gamma$-irradiation at $40 \mathrm{KGray}$ in plastic bags sealed under vacuum ; they were distributed to the rats ad libitum in the form of a paste.

The method used to estimate mineral absorption has already been described (Andrieux and Sacquet, 1983). Briefly, a transit marker was incorporated into the diet long enough for marker excretion to equal marker intake. The 8 rats of each group were then killed at regular intervals over a 24-hour period, or at the rate of one rat every $3 \mathrm{~h}$ beginning at $16 \mathrm{~h}$. The last $5 \mathrm{~cm}$ of the small intestine, cecum, proximal colon and distal colon were rapidly emptied of their contents. The ratio $R$ (minerals/transit marker) was determined in the diet and at the above levels, $N$, of the digestive tract. The arithmetic mean of the $R$ values found over

TABLE 1

Diet composition (\%)

\begin{tabular}{|c|c|}
\hline Maize starch & 58 \\
\hline Casein & 20.5 \\
\hline Maize oil & 9 \\
\hline Cellulose & 5 \\
\hline Mineral mixture $(*)$ & 4.5 \\
\hline dditional vitamins and amino acids (** & 3 \\
\hline
\end{tabular}

(*) The mineral mixture includes (in $\mathrm{g} \% \mathrm{~g}$ of diet) : Calcium carbonate 1.3 ; monocalcium phosphate 0.55 ; dipotassium phosphate 1.125 ; disodium phosphate 0.5 ; sodium chloride 0.25 ; magnesium sulfate 0.6 ; iron citrate 0.1 ; zinc sulfate 0.025 ; manganese sulfate 0.040 ; copper sulfate 0.006 ; potassium iodide 0.005 ; cobalt chloride 0.001 . The mineral composition of each preparation was controlled by essay. The complete diet contained a mean (in $\mathrm{mg} / \mathrm{g}$ dry matter) of $\mathrm{Ca}: 8.2 ; \mathrm{P}: 6.7 ; \mathrm{Mg}: 0.7$.

$\left(^{* *}\right)$ In Andrieux, Guéguen and Sacquet, 1980. 
$24 \mathrm{~h}$ compared to the $\mathrm{R}$ value of the diet gave mean apparent mineral absorption between intake and a level, $N$, of the digestive tract.

Apparent absorption, A, was expressed in percentage of mineral ingested by the formula :

$$
A=\left(1-\frac{\bar{R} \text { level } N}{\bar{R} \text { of } \operatorname{diet}}\right) \times 100
$$

The results, expressed by the mean \pm SEM, were analysed statistically by the method of Neuman-Keuls modified by Duncan (1955).

Analytical methods. - The $\mathrm{TiO}_{2}$, insoluble in strong acids and bases, was easily separated from the calcium and the other minerals after the samples had been ashed as follows. 100 to $200 \mathrm{mg}$ of dry matter were ashed at $550{ }^{\circ} \mathrm{C}$ for $16 \mathrm{~h}$. This ash was re-dissolved in $10 \%$ hot $\mathrm{HNO}_{3}$ and the insoluble $\mathrm{TiO}_{2}$ was separated from the other minerals by centrifugation at $35000 \times \mathrm{g}$ for $10 \mathrm{~min}$. All the minerals, except $\mathrm{P}$, were assayed in the supernatant by atomic absorption spectrometry (apparatus IL 151). Phosphorus was assayed by Misson's reaction. The $\mathrm{TiO}_{2}$ was mixed in potassium sulfate acid and dissolved at $100{ }^{\circ} \mathrm{C}$ in $\mathrm{H}_{2} \mathrm{SO}_{4} 2 \mathrm{~N}$. The addition of $\mathrm{H}_{2} \mathrm{O}_{2}$ caused a staining reaction proportional to the amount of $\mathrm{TiO}_{2}$. Staining intensity was determined at $410 \mathrm{~nm}$. This method revealed the marker when $10 \mu \mathrm{g}$ or more of it were present.

\section{Results.}

Dietary intake, body weight and cecal weight (table 2). - The amount of dietary intake by the 48 rats was $13.05 \pm 1.4 \mathrm{~g}$, it was not significantly changed by the ingestion of MRP. The body weight of GF rats ingesting diet M3 was a little lower than that of the other rats. The weight of the cecal contents was not changed but cecal water content was higher in the GFM1.5 and M3 groups than in the GFC group.

TABLE 2

Weight of body and of cecum.

\begin{tabular}{|c|c|c|c|c|c|c|}
\hline \multirow{2}{*}{$\frac{\text { Type of rats }}{\text { Diet }}$} & \multicolumn{3}{|c|}{ Germfree (GF) } & \multicolumn{3}{|c|}{ Conventional (CV) } \\
\hline & C & M1.5 & M3 & $c$ & M1.5 & M3 \\
\hline $\begin{array}{l}\text { Body weight }(g) \\
\text { Weight of cecal }\end{array}$ & $314 \pm 4^{b}$ & $310 \pm 4^{b}$ & $288 \pm 3^{a}$ & $302 \pm 5^{b}$ & $310 \pm 3^{b}$ & $308 \pm 5^{b}$ \\
\hline $\begin{array}{l}\text { content }(\mathrm{g}) \\
\text { Cecal water }\end{array}$ & $14.5 \pm 0.3^{f}$ & $14.2 \pm 0.2^{f}$ & $13.7 \pm 0.6^{f}$ & $2.40 \pm 0.14^{c}$ & $3.4 \pm 0.2^{d}$ & $4.3 \pm 0.3^{\mathrm{e}}$ \\
\hline content $(\%)$ & $82.2 \pm 0.5^{h}$ & $87.0 \pm 0.4^{i}$ & $87.6 \pm 0.5^{i}$ & $76.6 \pm 0.7^{9}$ & $77.7 \pm 0.3^{\mathrm{g}}$ & $77.8 \pm 0.1^{9}$ \\
\hline
\end{tabular}

Results are shown in $\bar{m} \pm \operatorname{SEM}(8$ rats per lot).

Values with the same superscript are not significantly different $(P<0.05)$ according to the Newman-Keuls test. 
The ingestion of MRP did not affect the body weight of $\mathrm{CV}$ rats. On the contrary, the more MRP there were in the diet, the higher was the weight of the cecal contents. Cecal water content was not changed significantly.

Minera/ absorption. - The total apparent mineral absorption of GF rats could not be computed due to poor separation of feces and urine. This estimate was made by measuring absorption between the mouth and the distal colon.

Calcium (table 3). - GF rats ingesting diet M3 showed lower apparent $\mathrm{Ca}$ absorption from the mouth to the terminal ileum than the other groups of rats. This effect was not compensated for in the cecum or colon and $\mathrm{Ca}$ retention was lower in this group than in the control group. Absorption was not significantly reduced with diet $M 1.5$, although $C a$ retention was significantly lower. $C V$ rats ingesting MRP also showed lower apparent $\mathrm{Ca}$ absorption in the small intestine ;

\section{TABLE 3}

Apparent absorption of calcium from intake to a digestive tract level total apparent absorption and retention (in \% of intake).

\begin{tabular}{|c|c|c|c|c|c|c|}
\hline \multirow{2}{*}{$\frac{\text { Type of rats }}{\text { Level }}$} & \multicolumn{3}{|c|}{ Germfree (GF) } & \multicolumn{3}{|c|}{ Conventional (CV) } \\
\hline & $C$ & $M 1.5$ & M3 & $C$ & M1.5 & M3 \\
\hline $\begin{array}{l}\text { Terminal ileum } \\
\text { Cecum } \\
\text { Proximal colon } \\
\text { Distal colon }\end{array}$ & $\begin{array}{l}19.0 \pm 2.4^{\mathrm{bc}} \\
25.3 \pm 1.5^{\mathrm{d}} \\
26.8 \pm 2.3^{\mathrm{d}} \\
27.6 \pm 1.4^{\mathrm{d}}\end{array}$ & $\begin{array}{l}16.1 \pm 3.6^{\mathrm{ab}} \\
21.7 \pm 1.6^{\mathrm{bcd}} \\
22.4 \pm 1.4^{\mathrm{bcd}} \\
22.4 \pm 1.3^{\mathrm{bcd}}\end{array}$ & $\begin{array}{l}13.2 \pm 3.6^{\mathrm{a}} \\
14.3 \pm 2.4^{\mathrm{ab}} \\
17.6 \pm 1.7^{\mathrm{ab}} \\
18.3 \pm 2.0^{\mathrm{bc}}\end{array}$ & $\begin{array}{l}17.8 \pm 3.4^{b c} \\
21.1 \pm 1.4^{b c d} \\
20.7 \pm 1.7^{b c d} \\
21.8 \pm 1.4^{b c d}\end{array}$ & $\begin{array}{l}11.0 \pm 3.1^{\mathrm{a}} \\
23.0 \pm 1.0^{\mathrm{bcd}} \\
21.3 \pm 1.3^{\mathrm{bcd}} \\
23.9 \pm 2.3^{\mathrm{bcd}}\end{array}$ & $\begin{array}{l}12.5 \pm 3.6^{\mathrm{a}} \\
22.9 \pm 2.3^{\mathrm{bc}} \\
23.0 \pm 1.3^{\mathrm{bcd}} \\
25.0 \pm 1.2^{\mathrm{d}}\end{array}$ \\
\hline $\begin{array}{l}\text { Total absorp- } \\
\text { tion (from in- } \\
\text { take to feces) }\end{array}$ & & & & $21 \pm 1.3^{\mathrm{bcd}}$ & $23.0 \pm 1.4^{b c}$ & $24.9 \pm 1.0^{\mathrm{d}}$ \\
\hline Retention & $25.5 \pm 1.2^{d}$ & $18.0 \pm 2.2^{b c}$ & $16.2 \pm 1.4^{\mathrm{ab}}$ & $18.1 \pm 1.2^{\mathrm{bc}}$ & $20.5 \pm 1.6^{b c}$ & $19.3 \pm 1.2^{\mathrm{bcd}}$ \\
\hline
\end{tabular}

Results are shown in $\overline{\mathrm{m}} \pm \operatorname{SEM}(8$ rats per lot).

Values with the same superscript are not significantly different $(P<0.05$ ) according to the NewmanKeuls test.

this effect was significant with diets M1.5 and M3. Contrary to GF rats, this effect was entirely compensated for in the cecum and colon.

Phosphorus (table 4). - Apparent $\mathrm{P}$ absorption was not modified significantly by the ingestion of MRP in any part of the digestive tract in either GF or CV rats. On the other hand, phosphorus retention was lower in GFM3 rats than in the other groups, suggesting an increase in urinary $P$ excretion in these rats.

Magnesium (table 5). - Apparent magnesium absorption in the small intestine was significantly reduced in GFM3 rats. Mg absorption in the hindgut was about 
TABLE 4

Apparent absorption of phosphorus from intake to a digestive tract level, total apparent absorption and retention (in \% of intake).

\begin{tabular}{lcccccc}
\hline Type of rats & \multicolumn{3}{c}{ Germfree (GF) } & \multicolumn{3}{c}{ Conventional (CV) } \\
\hline \multicolumn{1}{c}{ Diet } & $\mathrm{C}$ & $\mathrm{M} 1.5$ & $\mathrm{M} 3$ & $\mathrm{C}$ & $\mathrm{M} 1.5$ & $\mathrm{M} 3$ \\
Level & & & & & & \\
\hline Terminal ileum & $45.3 \pm 3.7^{\mathrm{ab}}$ & $50.0 \pm 1.8^{\mathrm{bc}}$ & $47.4 \pm 1.9^{\mathrm{bc}}$ & $40.1 \pm 2.4^{\mathrm{a}}$ & $42.0 \pm 3.3^{\mathrm{a}}$ & $40.0 \pm 3.4^{\mathrm{a}}$ \\
Cecum & $49.4 \pm 1.4^{\mathrm{bc}}$ & $51.8 \pm 1.5^{\mathrm{bc}}$ & $49.4 \pm 1.3^{\mathrm{bc}}$ & $49.0 \pm 2.0^{\mathrm{bc}}$ & $51.0 \pm 1.0^{\mathrm{bc}}$ & $51.4 \pm 1.4^{\mathrm{bc}}$ \\
Proximal colon & $50.0 \pm 1.8^{\mathrm{bc}}$ & $48.2 \pm 1.9^{\mathrm{bc}}$ & $45.7 \pm 1.8^{\mathrm{bb}}$ & $50.2 \pm 2.3^{\mathrm{bc}}$ & $51.8 \pm 1.3^{\mathrm{c}}$ & $51.8 \pm 1.5^{\mathrm{bc}}$ \\
Distal colon & $52.2 \pm 1.6^{\mathrm{c}}$ & $50.0 \pm 1.2^{\mathrm{bc}}$ & $47.7 \pm 2.3^{\mathrm{bc}}$ & $49.2 \pm 1.1^{\mathrm{bc}}$ & $53.8 \pm 1.6^{\mathrm{bc}}$ & $51.8 \pm 1.7^{\mathrm{bc}}$ \\
\hline $\begin{array}{l}\text { Total absorp- } \\
\text { tion (from in- } \\
\text { take to feces) }\end{array}$ & & & & & & \\
\hline Retention & $17.0 \pm 1.7^{\mathrm{d}}$ & $19.8 \pm 3.7^{\mathrm{d}}$ & $10.1 \pm 2.7^{\mathrm{e}}$ & $15.9 \pm 1.6^{\mathrm{d}}$ & $16.5 \pm 1.1^{\mathrm{d}}$ & $18.3 \pm 1.3^{\mathrm{d}}$ \\
\hline
\end{tabular}

Results are shown in $\bar{m} \pm$ SEM $(8$ rats per lot).

Values with the same superscript are not significantly different $(P<0.05)$ according to the NewmanKeuls test.

\section{TABLE 5}

Apparent absorption of magnesium from intake to a digestive tract level, total apparent absorption and retention (in \% of intake).

\begin{tabular}{|c|c|c|c|c|c|c|}
\hline \multirow{2}{*}{$\frac{\text { Type of rats }}{\text { Level }}$} & \multicolumn{3}{|c|}{ Germfree (GF) } & \multicolumn{3}{|c|}{ Conventional (CV) } \\
\hline & c & M1.5 & M3 & C & M1.5 & M3 \\
\hline $\begin{array}{l}\text { Terminal ileum } \\
\text { Cecum } \\
\text { Proximal colon } \\
\text { Distal colon }\end{array}$ & $\begin{array}{l}28.8 \pm 5.0^{b c} \\
66.9 \pm 1.1^{f} \\
67.3 \pm 1.5^{f} \\
69.0 \pm 1.5^{f}\end{array}$ & $\begin{array}{l}30.6 \pm 3.3^{c} \\
62.0 \pm 1.6^{f} \\
67.0 \pm 1.6^{f} \\
68.3 \pm 2.3^{f}\end{array}$ & $\begin{array}{l}15.4 \pm 5.0^{\mathrm{a}} \\
51.9 \pm 3.3^{\mathrm{de}} \\
54.2 \pm 2.8^{\mathrm{e}} \\
55.1 \pm 1.8^{\mathrm{e}}\end{array}$ & $\begin{array}{l}27.1 \pm 3.5^{\mathrm{bc}} \\
43.8 \pm 2.1^{\mathrm{d}} \\
46.1 \pm 2.7^{\mathrm{de}} \\
46.5 \pm 2.5^{\mathrm{de}}\end{array}$ & $\begin{array}{l}11.5 \pm 3.9^{\mathrm{a}} \\
46.1 \pm 1.6^{\mathrm{de}} \\
48.5 \pm 1.4^{\mathrm{de}} \\
52.3 \pm 1.4^{\mathrm{de}}\end{array}$ & $\begin{array}{l}15.3 \pm 2.5^{\mathrm{a}} \\
51.1 \pm 2.9^{\mathrm{de}} \\
51.8 \pm 2.1^{\mathrm{de}} \\
54.2 \pm 1.9^{\mathrm{e}}\end{array}$ \\
\hline $\begin{array}{l}\text { Total absorp- } \\
\text { tion (from in- } \\
\text { take to feces) }\end{array}$ & & & & $45.0 \pm 1.4^{d}$ & $52.0 \pm 1.2^{\mathrm{de}}$ & $58.4 \pm 1.4^{\mathrm{e}}$ \\
\hline Retention & $26.8 \pm 1.2^{\mathrm{bc}}$ & $17.3 \pm 2.1^{\mathrm{a}}$ & $15.3 \pm 1.6^{\mathrm{a}}$ & $17.0 \pm 1.5^{\mathrm{a}}$ & $15.4 \pm 1.8^{a}$ & $16.5 \pm 1.3^{\mathrm{a}}$ \\
\hline
\end{tabular}

Results are shown in $\bar{m} \pm$ SEM (8 rats per lot).

Values with the same superscript are not significantly different $(P<0.05)$ according to the NewmanKeuls test.

equal in the various groups of GF rats so that total absorption (estimated from intake to the distal colon) remained lower in GFM3 rats. Mg retention was lower in the GFM1.5 and M3 groups than in the controls, indicating an increase in urinary excretion of $\mathrm{Mg}$ in group M1.5. MRP reduced $\mathrm{Mg}$ absorption in the small intestine of CV rats ; as in the case of calcium, this effect was significant in the CVM1.5 and M3 groups. It was entirely compensated for in the cecum and colon 
by an increase in apparent Mg absorption. In group CVM3, total absorption was higher than in the other groups but retention was comparable, resulting from an effect of MRP on urinary excretion of magnesium.

\section{Discussion and conclusions.}

These results show that MRP prepared from glycine and glucose changed the apparent absorption of some minerals. They reduced apparent $\mathrm{Ca}$ and $\mathrm{Mg}$ absorption in the small intestine of GF and CV rats. On the contrary, they had no effect on apparent $P$ absorption. The lower retention of $P$ in GF rats ingesting MRP might be related to a lower $\mathrm{Ca}$ retention. The lower apparent absorption of $\mathrm{Ca}$ and $\mathrm{Mg}$ in the small intestine could be due either to MRP-mineral binding or to MRP action on enterocyte metabolism. Favoring the first hypothesis is the fact that divalent ions in vitro speed up the formation of MRP (Reynold, 1965) and that $\mathrm{Ca}$ stabilizes some of their constituents (Petit, 1959). However, $\mathrm{Mg}$ and $\mathrm{Ca}$ absorption was not significantly lower in the cecum and colon of GF rats. The difference in absorption between the ileum and distal colon was about $40 \%$ for $\mathrm{Mg}$ in the three groups of GF rats; it was not significantly lowered by MRP for $\mathrm{Ca}: 8.6,6$ and $5 \%$ in GFC, GFM1.5 and GFM3, respectively. This would indicate that MRP action in vivo was not due to MRP-mineral binding because absorption would have been reduced all along the digestive tract. On the other hand, the second hypothesis, i.e. the direct action of MRP on enterocytes, would explain the observed effect of MRP on disaccharidase activity (Lee, Chichester and Lee, $1977)$ and on protease and amylase activities, suggesting that the action of these substances is generally antienzymatic (Adrian, 1974).

Contrary to GF rats, apparent mineral absorption in the cecum of $\mathrm{CV}$ rats was favored by MRP. The higher the MRP content of the diet, the greater was the effect. Previously the rare authors who studied the effect of MRP on mineral metabolism showed an increase in calcium absorption in $\mathrm{CV}$ rats (Adrian and Boisselot-Lefebvres, 1977 ; Senior, Wolinsky and Brinkman, 1978). This increase of apparent calcium absorption was not significant in our experiment. On the other hand, total apparent absorption of magnesium and phosphorus was higher in group CVM3 than in the controls. The unfavorable effect of MRP in the small intestine was thus entirely compensated for by MRP. formation in the colon. In the present state of our knowledge, it is difficult to determine the mechanism by which microflora hydrolysis of MRP contributes to an increase in mineral absorption in the cecum. It may be that these hydrolized products act on mucosal permeability or that their absorption shown by some authors (Tanaka, Lee and Chichester, 1975 ; Johnson, Baker and Perkins, 1979) is accompanied by mineral absorption. The increase in cecal weight and thus of the cecal absorptive surface would also increase the absorption of certain minerals. In GF which have a large cecum, the absorption of $\mathrm{Ca}, \mathrm{Mg}$ and $\mathrm{P}$ is higher at this level. Whatever the mechanism, the best absorption of $\mathrm{Mg}$ and $\mathrm{P}$ in CVM3 rats was not accompanied by an increase in the retention of these minerals. Some authors have shown considerable urinary excretion of MRP or of their bacterial 
metabolites (Mori and Nakatsuji, 1977 ; Tanaka, Lee and Chichester, 1975) and renal hypertrophy as a result of their ingestion (Adrian, 1974 ; Adrian, BoisselotLefebvres, 1977). The increased urinary excretion of minerals could be related to the excretion of MRP.

Reçu en novembre 1983. Accepté en février 1984.

Résumé. Effet des produits de la réaction de Maillard sur l'absorption apparente des minéraux, à différents niveaux du tractus digestif. Rôle de la flore.

L'ingestion de produits de la réaction de Maillard (PRM), préparés par chauffage de glycine et de glucose, aux taux de 1,5 et $3 \%$ dans un aliment irradié, provoque chez des rats axéniques (GF) et holoxéniques (CV) une modification de l'absorption apparente du calcium et du magnésium. L'absorption de ces minéraux est réduite dans l'intestin grêle des rats CV et GF, peut-être par action des PRM sur le métabolisme de l'entérocyte. Cet effet est compensé, chez les seuls rats CV, par une augmentation de l'absorption de ces minéraux au niveau du cacum. La présence de la flore microbienne, l'augmentation du volume cæcal chez les rats $C V$, suggèrent que la fermentation des PRM est responsable de l'absorption accrue des minéraux dans le cæcum et le côlon. Cependant, bien que l'absorption apparente totale du calcium, du magnésium et du phosphore soit plus importante chez les rats CV qui ingèrent des PRM, leur excrétion urinaire est également plus élevée et la rétention de ces minéraux n'est pas améliorée. Chez les rats GF, l'effet des PRM n'est pas compensé dans le cæcum et la rétention des minéraux est significativement réduite.

\section{References}

ADRIAN J., 1974. Nutritional and physiological consequences of the Maillard reaction. World Rev. Nutr. Diet., 19, 71-122.

ADRIAN J., BOISSELOT-LEFEBVRES J., 1977. Interrelations entre les produits de la réaction de Maillard et le métabolisme calcique. Cah. Nutr. Diet., 12, 233-234.

ADRIAN J., FRANGNE R., 1973. La réaction de Maillard. 8. Influence des prémélanoïdines sur la digestibilité azotée et la protéolyse. Ann. Nutr. Alim., 27, 111-123.

ANDRIEUX C., GUÉGUEN L., SACQUET E., 1980. Effects of lactose and mode of sterilization of a lactose diet on mineral metabolism in germfree and conventional rats. Reprod. Nutr. Dévelop., 20, 119-138.

ANDRIEUX C., SACQUET E., 1983. Effect of microflora and lactose on the absorption of calcium, phosphorus and magnesium in the hindgut of the rat. Reprod. Nutr. Dévelop., 23, 259-271.

ANDRIEUX C., SACQUET E., GUÉGUEN L., 1980. Interactions between Maillard's reaction products, the microflora of the digestive tract and mineral metabolism. Reprod. Nutr. Dévelop., 20, 1061-1069.

DUNCAN D. B., 1955. Multiple range and multiple F Tests. Biometrics, 11, 1-42.

LEE C. M., CHICHESTER C. O., LEE T. C., 1977. Effect of Maillard reaction products on disaccharidase activities in the rat. J. agric. Food. Chem., 25, 775-778.

JOHNSON G. H., BAKER D. H., PERKINS E. G., 1979. Nutritional implications of the Maillard reaction. The metabolism of fructose-phenylalanine in the rat. J. Nutr., 109, 590-596.

MORI B., NAKATSUJI H., 1977. Utilization in rats of ${ }^{14} \mathrm{C}-\mathrm{L}$ lysine-labeled casein browned by aminocarbonyl reaction. Agric. biol. Chem., 41, 345-350.

NESHEIM M. C., CARPENTER K. J., 19667. The digestion of heat-damaged protein. Brit. J. Nutr, 21, 399-411.

PETIT L., 1959. Recherches sur la réaction de Maillard. Ann. Technol., 1, 5-33. 
REYNOLD T. M., 1965. Chemistry of non-enzymatic browing-II. Adv. Food Res., 14, 168-283.

SENIOR J. A., WOLINSKY I., BRINKMAN G. L., 1978. Diets based on autoclaved skim milk powder. Caries Res., 12, 275-283.

SGARBIERI V. C., AMAYA J., TANAKA M., CHICHESTER C. O., 1972. Nutritional consequences of the Maillard reaction. Amino acid availability from fructose-leucine and fructose-tryptophan in the rat. $J$. Nutr., 103, 657-663.

TANAKA M., LEE T. C., CHICHESTER C. O., 1975. Nutritional consequences on the Maillard reaction. The absorption of fructose-L.-tryptophan in the large intestine of the rat. J. Nutr., 105, 989-994.

VALLE-RIESTRA J., BARNES R. H., 1970. Digestion of heat-damaged egg albumen by the rat. J. Nutr., 100, 873-882. 